\title{
Influencers of Inflation in Ghana
}

\author{
Dr. Emmanuel Acquah-Sam \\ Senior Lecturer, Wisconsin International University College, \\ North-Legon, Ghana
}

doi: 10.19044/esj.2017.v13n7p140 URL:http://dx.doi.org/10.19044/esj.2017.v13n7p140

\begin{abstract}
The effects of inflation on the economic life of the citizenry of a country and the theoretical causes have led to numerous researches in the area. Annual inflation rates in Ghana since 1990 show a fluctuating trend depicting how unsuccessful various governments and policy-makers have battled with changes in the general price level. The theoretical and empirical literature on inflation seem to suggest that the causes of inflation are multifaceted, and time specific, as well as dependent on the level of development of a country. This paper attempts to explore some of major triggers of inflation Ghana for decision-making and implementation as well as adding to existing researches in the area. It uses multiple linear regression analysis based on structural equation modelling through path analysis. It concludes that interest rate, proxied by Treasury bill rates, is the only major variable that has a positive and significant effect on inflation in Ghana with regard to the time period studied. Factors such as GDP growth, market capitalisation, gross fixed investment, and foreign direct investments proved insignificant in influencing inflation in Ghana. This study lends support to the fact that inflation reacts positively to changes in interest rates, therefore, governments and policy-makers must consider it critical when pursuing propoor growth policies.
\end{abstract}

Keywords: Ghana, inflation, quantity theory of money, regression analysis, interest rate

\section{Introduction}

Many people discuss inflation, though its real meaning and effects seem to be misunderstood. Governments in power have used fallen trends in inflation rates to express the strength of their macroeconomic policies in solving economic problems. On the contrary, opposing parties have used high rates of inflation to criticize the efforts of governments in power. No matter how the subject seems to be presented, anybody who neglects its power does so at his/her own peril. The study of causes of inflation is 
important because excessive inflation reduces the level of business investments, and the efficiency with which productive factors are utilised.

Economists define inflation as persistent and appreciable increase in the general price level over a period of time. The layman on the street may simply define inflation as a situation where too much money chases few goods and services. Slavin (2002) writes, if you ask the man on the street what inflation means, he will tell you that everything costs more. The newspapers sometimes report that inflation rate has reduced. However, we see that within the same period, prices of goods and services would still be high. The simple reason is that once there is inflation it means prices are rising. This is technically referred to as disinflation. On the other hand, if prices are falling, it is referred to as deflation (this is rare to experience in most developing countries). This means that to discuss inflation, it must be recognised that prices of goods and services are generally and significantly rising over a reasonable period of time. What have become sources of worry to many are the causes of inflation and how it can be tackled.

In the theoretical exploration of the causes of inflation by Totonchi (2011), inflation is caused by monetary shocks, demand-side shocks, supplyside (or real) shocks, structural, and political factors (the role of institutions), and present inflation. Sergent \& Wallace (1981) and Montiel (1989, cited in Totonchi, 2011) write that the major cause of inflation in developed countries is growth of money supply. On the contrary, in developing countries, inflation is not a purely monetary phenomenon, but higher money growth and exchange rate depreciation arising from a balance of payments crisis dominate the inflation process in developing countries.

Various researchers in Ghana report on some of the causes of inflation, and still recommend further studies into the subject. ISSER (2009) report that the single digit inflation objective set for 2008 was impossible to realise, because of rising crude oil prices and the energy crisis experienced by the country, as well as high election year expenditures. Again, Adu \& Marbuah (2011) write that real output, nominal exchange rate, broad money supply, nominal interest rate and fiscal deficit play a dominant role in the inflationary process in Ghana to the extent that output growth has been the strongest impact on inflation. Their paper concludes that inflation in Ghana is explained by a combination of structural and monetary factors. Also, Oppong, Abruquah, Agyeiwaa, Owusu, Quaye, \& Ashalley (2015) reveal that crude oil price at the world market, exchange rate, and Electioneering Spillover Quaternary Effects (ESQE) are key determinants of inflation in Ghana. Gyebi \& Boafo (2013) also realise that real exchange rate and money supply are the main macroeconomic factors responsible for inflation in Ghana. In addition, Enu, \& Havi (2014) identify population growth, foreign direct investment, foreign aid, and service's output as major long run 
determinants of inflation in Ghana. BoG (2016) mentions that annual headline inflation rose steadily from 16.4 percent in January to 17.9 percent in July 2015. This was driven by the effects of currency depreciation, upward adjustment in ex pump prices following deregulation of petroleum prices, and increased food prices arising from the cyclical dry season. Table 1.1 presents the annual inflation rates in Ghana from 1990 to 2015.

The economic life of every country is dynamic, and the variables affecting inflation continue to assume different dimensions. Again, the theoretical and empirical literature on inflation seem to suggest that the causes of inflation are multifaceted, and time specific, as well as dependent on the level of development of a country. A critical look at the rates of inflation in Ghana (Table 1.1) shows a fluctuating inflationary trend since 1990 depicting how unsuccessful various governments of Ghana have battled with changes in the general price level in their attempts to promote pro-poor economic growth, despite the Bank of Ghana's practice of inflation targeting. This article adds to existing literature by exploring some of the major triggers of inflation for decision-making and implementation from 1990 to 2011. In the next section, the theoretical and empirical writings on inflation will be analysed.

Table 1.1 Annual Rates of Inflation in Ghana from 1990 to 2015

\begin{tabular}{|c|c|}
\hline Year & Percentage (\%) Rate \\
\hline 1990 & 13.03 \\
\hline 1991 & 34.2 \\
\hline 1992 & 34.2 \\
\hline 1993 & 70.8 \\
\hline 1994 & 32.7 \\
\hline 1995 & 20.8 \\
\hline 1996 & 15.7 \\
\hline 1997 & 13.8 \\
\hline 1998 & 40.5 \\
\hline 1999 & 21.3 \\
\hline 2000 & 15.2 \\
\hline 2001 & 23.6 \\
\hline 2002 & 11.8 \\
\hline 2003 & 14.8 \\
\hline 2004 & 10.9 \\
\hline 2005 & 12.7 \\
\hline 2006 & 10.5 \\
\hline 2007 & 12.7 \\
\hline 2008 & 18.13 \\
\hline 2009 & 20.06 \\
\hline 2010 & 6.7 \\
\hline 2011 & 7.68 \\
\hline 2012 & 7.07 \\
\hline 2013 & 11.67 \\
\hline 2014 & 15.49 \\
\hline 2015 & 17.15 \\
\hline
\end{tabular}

Source: Databank Research, Graphic Business, Tuesday, February 24 - March 2, 2009 (1990 - 2009); https://www.statista.com/statistics/447576/inflation-rate-in-ghana (2010 2015) 


\section{Literature Review}

The quantity theory of money developed in the $19^{\text {th }}$ century asserts that changes in the general price level are determined primarily by changes in the quantity of money in circulation in an economy. The quantity theory of money is a theory about the demand for money in an economy. In the 1900s, Irving Fisher of Yale University developed a model of money demand also known as equation of exchange, $\mathrm{MV}=\mathrm{PT}$. Where $\mathrm{M}$ is quantity of money; $\mathrm{V}$ is velocity of circulation; $\mathrm{P}$ is general price level; and $\mathrm{T}$ is volume of transaction. “T” was also represented by $\mathrm{Y}$, which measures aggregate output or aggregate income. Therefore, PY represents total spending on goods and services. He suggested that as the amount of money in circulation increases, the price level also increases in direct proportion and the value of money decreases and vice versa, other things being equal. According to Totonchi (2011), Fisher and other neo-classical economists, such as Arthur Cecil Pigou (1877-1959) of Cambridge, monetary control could be achieved in a fractional reserve-banking regime through control of an exogenously determined stock of high power money.

Building on the works of earlier scholars, including Irving Fisher, Milton Friedman argues that demand for real money balances $\left(M_{d} / P\right)$ is directly related to permanent income $\left(Y_{p}\right)$, the discounted present value of expected future income, and indirectly related to the expected differential returns from bonds, stocks (equities), and goods vis-à-vis money ( $\mathrm{r}_{\mathrm{b}}-\mathrm{r}_{\mathrm{m}}, \mathrm{r}_{\mathrm{s}}-$ $\left.r_{m}, \pi^{e}-r_{m}\right)$, where inflation $(\pi)$ proxies the return on goods. His reason is that the return on money would increase or decrease as returns on bonds, stocks, and goods increased or decreased. Friedman does not think that interest rate changes matter much (http://2012books.lardbucket.org/pdfs/finance-banking-and-moneyv2.0.pdf). Stated more formally,

$M d / P: f\left(Y p<+>, r b-r m<->, r s-r m<->, \pi e^{-r m}<->\right)$

- where

- $\quad \mathrm{M}_{\mathrm{d}} / \mathrm{P}=$ demand for real money balances $\left(\mathrm{M}_{\mathrm{d}}=\right.$ money demand; $\mathrm{P}=$ price level)

- $\quad f$ means “function of” (not equal to)

- $\quad \mathrm{Y}_{\mathrm{p}}=$ permanent income

- $\quad \mathrm{r}_{\mathrm{b}}-\mathrm{r}_{\mathrm{m}}=$ the expected return on bonds minus the expected return on money

- $\quad \mathrm{r}_{\mathrm{s}}-\mathrm{r}_{\mathrm{m}}=$ the expected return on stocks (equities) minus the expected return on money

- $\quad \pi^{\mathrm{e}}-\mathrm{r}_{\mathrm{m}}=$ expected inflation minus the expected return on money

- $<+>=$ increases in

- $\quad<->=$ decreases in 
John Maynard Keynes is reported to have rejected the direct relationship between $\mathrm{M}$ and $\mathrm{P}$, because it ignored the role of interest rates. Keynes also argued that the process of money circulation is complicated and not direct, so individual prices for specific markets adapt differently to changes in the money supply. Keynes believed inflationary policies could help stimulate aggregate demand and boost short-term output to help an economy achieve full employment sectors (http://www.investopedia.com/terms/q/quantity_theory_of_money.asp\#ixzz4 VwdmsitQ).

Modern exponents of inflation have summarised the causes of inflation into demand-pull inflation cost-push inflation, and mixed-demand inflation.

- $\quad$ Demand-pull inflation occurs when an increase in aggregate demand for goods and services increases the price level.

- $\quad$ Cost-push inflation refers to increases in the general prices of goods and services that are caused by increases in cost of production. Nellis \& Parker (1996) report that, inflation rose to 11\% between 1974 and 1979 in response to the sharp increase in world oil price.

- $\quad$ Mixed-demand inflation is caused by both demand pull factors and cost push factors. Proponents of macroeconomics are of the view that, generally, it is difficult to distinguish between supply-side inflation and demand-side inflation. For instance, an increase in aggregate demand may raise firms' demand for labour and cause workers to demand higher wages; this in turn may lead firms to raise their prices. In such a case, the inflation may be demand-side in the sense that, the ultimate cause was an increase in aggregate demand, but it is supply-side in the sense that the proximate cause of the increase in the price level was an increase in wages (Mansfield \& Behravesh, 2001).

\section{Consequences of Inflation}

Inflation has both short term and long term effects on all economic agents that is why efforts are made by successive governments and policymakers to prescribe and implement appropriate policies to control its effects. Inflation has both positive and negative effects.

\section{- $\quad$ Positive Effects of Inflation}

The main advantage of inflation is that in a developing economy a reasonable rate of inflation between $6 \%$ and $7 \%$ is a catalyst for rapid growth of businesses, other things being equal. This is a usual feature of rapidly expanding economy where there is strong competition for resources as production increases. Nellis \& Parker (1996) report that in Japan's high growth years between 1960 and 1973, Japan recorded a relatively high rate of inflation of over $6 \%$. Another theoretical advantage of a high rate of 
inflation is that, it enables governments to control unemployment. The Philip's relationship between the rate of unemployment and inflation suggests that governments could engage in excessive spending in order to reduce the rate of unemployment in a country.

Also, inflation helps to redistribute income from those with high marginal propensity to consume (the poor) to those with high marginal propensity to save (the rich). The poor live from hand to mouth, but the rich save to invest. In a closed economy an equilibrium condition demands that saving be equal to investment. Therefore, higher saving rate must lead to a corresponding high rate of investments to ensure equilibrium national income. Simply put, increased saving on the part of the rich will lead to increased investments and employment.

\section{- $\quad$ Negative Effects of Inflation}

Inflation erodes the incomes of fixed income earners such as pensioners, those who receive unemployment benefits and fixed deposit holders. Milton Friedman wrote that inflation is a form of taxation that can be imposed without legislation. Again, inflation causes balance of payment problems for a country. High rates of inflation cause locally produced goods and services to become very expensive relative to foreign goods and services and these locally produced goods become less competitive in foreign markets. This reduces the volume and the amount of revenue from a country's exports of goods and services.

Also, galloping inflation rates of about $80 \%$, $200 \%$, or $1000 \%$ per day, month, or week, can reduce an economy to barter trade or cause it to collapse altogether in the long run. In such situations, money ceases to be a useful medium of exchange, and sometimes leads to a drop in output. Debtors benefit by repaying debts in cheaper currencies. Inflation reduces investors' confidence. How then can inflation be controlled to ensure that it benefits all stakeholders?

\section{Controlling Inflation}

Inflation is managed by both discretionary policies and nondiscretionary policies. Discretionary fiscal and monetary policies are pursued to achieve full-employment noninflationary gross domestic product and economic growth (McConnell \& Brue, 1996). These may also be expansionary and contractionary policies. A discretionary policy is supported because it allows policy-makers to respond quickly to events. However, when too much discretionary powers are given to the policy-makers, it may lead to economic mismanagement and dynamic inconsistencies. This must be assessed on the basis of whether inflation is caused by demand factors or supply factors or both. On the other hand, nondiscretionary policies are 
sometimes referred to as built-in-stabilizer or automatic stabilizer as well as rule-based.

An automatic stabilizer is any mechanism in the economy without case-by-case government intervention to reduce the amount by which output changes in response to a shock to the economy. According to Dornbusch, Fisher, \& Startz (2004), it is a mechanism that increases government's budget deficit or reduces its surplus during a recession, and increases government's budget surplus or reduces its deficit during inflation without any action by policy-makers. Kydland \& Prescott (1977, cited in Sauer, 2007) report that rule-based policy-making can increase welfare. In Section 2.3.1 the findings of some empirical studies conducted in the study area will be considered.

\section{Empirical Findings}

In a review of writings on causes of inflation, Totonchi (2011) reports that Sergent \& Wallace (1981) and Montiel (1989) write that the major cause of inflation in developed countries is growth of money supply. In developing countries, in contrast, inflation is not a purely monetary phenomenon. Higher money growth and exchange rate depreciation arising from a balance of payments crisis dominate the inflation process in developing countries.

Pettinger (2011) writes that strong economic growth causes higher inflation. If aggregate demand in an economy expanded faster than aggregate supply, higher inflation rate is expected to be seen. If demand is rising faster than supply, this suggests that economic growth is higher than the long run sustainable rate of growth. Again, high growth lowers unemployment, but this may cause labour shortages. This fall in unemployment causes wages to increase which leads to higher inflation. Lim \& Sek (2015) indicate that GDP growth and imports of goods and services have the significant long run impact on inflation in low inflation countries. In addition, Andersson, Masuch, \& Schiffbauer (2009) investigation into the determinants of inflation differentials and price levels across the euro area countries show that inflation differentials are primarily determined by cyclical positions and inflation persistence. The persistence in inflation differentials appeared to be partly explained by administered prices and to some extent by product market regulations. Also money supply, national expenditure and GDP growth are the long run determinants of inflation in high inflation countries. Money supply, imports of goods and services and GDP growth have significant relationship with inflation in low inflation countries. Furthermore, Madiha, Zahib, Shoaib, Mahmood, \& Nyanab (2013) discover that the relationship between inflation and foreign direct investment is positive in Pakistan. 
Salmanpour, \& Bahloli (2011) studied the major factors affecting inflation in Iran and the relationship between inflation and inflation uncertainty for the period of 1989-2003. They focused on Friedman-Ball and Cukierman-Meltzer hypotheses. The Friedman-Ball hypothesis assumes a one-way correlation from inflation to inflation uncertainty. On the contrary, Cukierman and Meltzer hypothesise that inflation uncertainty is the cause of inflation not its effect. That means by increasing inflation uncertainty the inflation of society increases and vice versa. The results of the study show a unidirectional relationship from inflation to inflation uncertainty for a three month period. There is also, a two-way relationship between inflation and inflation uncertainty obtained for six and nine month periods. Also, for the six and nine month period, this relationship is more intensive than three month period. There is no relationship between inflation and inflation uncertainty for an annual period. Money supply and exchange rate growth in black market had positive effects on inflation and gross domestic product growth had no effects on inflation rate in the estimated model. They conclude that Friedman-Ball hypothesis is true in Iran for a quarterly period. In 6 and 9 month periods, in addition to Freidman-Ball hypothesis, Cukierman-Meltzer hypothesis is also true in the case. In the annual period none of these two hypotheses is substantiated in Iran for the abovementioned periods.

Oppong, Abruquah, Agyeiwaa, Owusu, Quaye, \& Ashalley (2015) reveal that crude oil price at the world market, exchange rate, and Electioneering Spillover Quaternary Effects (ESQE) are key determinants of inflation in Ghana. The findings indicate a positive relationship between crude oil price at the world market and inflation, cedi-dollar exchange rates and inflation as well as ESQE and inflation. Gyebi \& Boafo (2013) also find that real exchange rate and money supply are the main macroeconomic factors responsible for inflation in Ghana. While exchange rate depreciation helps reduce the level of inflation, growth in real output or expenditure and money supply exert pressure on price levels to move up. Furthermore, Enu, \& Havi (2014) identify population growth, foreign direct investment, foreign aid, and service's output as major long run determinants of inflation in Ghana. The study concludes that in the long run, population growth and service output affect inflation positively. However, foreign direct investment, foreign aid and agricultural output impact negatively. In the short run, the past two years inflation has a significant impact on the current inflation. Again, past one year and third years of inflation impact positively on current inflation. The population growth and foreign direct investment's past records have both positive and negative impact on current inflation. However, they are not significant. The past records of foreign aid and service output have positive effect on inflation while past records of agricultural 
output impact negatively on the inflation as expected. However, they are not significant. Ocran (2007; cited in Enu, \& Havi, 2014) identify inflation inertia, changes in money, changes in the government of Ghana treasury bill rates, and changes in the exchange rate, as determinants of inflation in the short run. He adds that, inflation inertia was the dominant determinant of inflation in Ghana.

Adu \& Marbuah (2011) identify real output, nominal exchange rate, broad money supply, nominal interest rate and fiscal deficit as playing dominant roles in the inflationary process in Ghana to the extent that output growth by far has the strongest impact on inflation. Their paper concludes that inflation in Ghana is explained by a combination of structural and monetary factors. In addition, Barimah, Quartey, \& Andinur (2013) portray a unidirectional causality was discovered running from GDP to inflation.

The literature reviewed reveal that the causes of inflation are multifaceted and that tackling inflation requires a multifaceted approach and attention must be paid to the time period in which policies are formulated and implemented to control inflation, because it determines the variables that cause inflation. The causes of inflation are also influenced by the level of development of a country. In section 3.1 an attempt is made to explain the method of analysis employed in the study.

\section{Methodology}

This study uses quantitative techniques for its analysis. It makes use of quarterly time series data from 1991 to 2011. It is the third of four models estimated by the author through the use of structural equation modelling through path analysis. It is underpinned by the modified version of the Quantity Theory of Money developed by Milton Friedman. The general multiple linear regression model for the study is as follows:

$\mathrm{a} 5 \mathrm{MKTt}+$ et

$$
\mathrm{Inf}_{\mathrm{t}}=\mathrm{a} 0+\mathrm{a} 1 \mathrm{~T}-\mathrm{BILLSt}+\mathrm{a} 2 \text { GDP growth }+\mathrm{a} \text { FFIt }+\mathrm{a} 4 \mathrm{GFIt}+
$$

Where, a0 is a constant. a1, a2, a3, a4, and a5 are the parameters or the coefficients of the variables under consideration. $t$ denotes time. The apriori expectations of the coefficients of the independent variables in the model are a0, a1, a2, a3, a4, a5, > 0. Inflation (Inf) served as dependent variable. The independent variables in the model are economic growth (GDP growth), gross capital formation (GFI), market capitalisation (MKT), foreign direct investment (FDI), and interest rate (proxied by the 91-Day government Treasury bill rates). The study initially considered nine (9) economic variables, namely market capitalisation (MKT), foreign direct investment (FDI), gross fixed investment (GFI), development of financial intermediation (DFI), total value of stocks traded (TVST), stock turnover ratio (STTO), TBILLS (treasury bills rates), Inflation, and GDP growth, but through 
principal component analysis DFI, TVST, and STTO were found to have weak influences and they were dropped.

Tools of analyses include Box-Cox mechanism; Principal Component Analysis (PCA); Structural Equation Modelling (SEM) through path analysis. The reasons for the choice of these methods are that they are multivariate techniques of analysis used to test hypotheses, and linear relationships between key variables (Cooper \& Schindler, 2011).

The theoretical relationship between inflation and economic growth appears ambiguous. According to WAMI (2012), Mundell (1965) and Tobin (1965) there is a positive relationship between the rate of inflation and the rate of economic growth. They argued that since money and capital are substitutable, an increase in the rate of inflation increases capital accumulation by shifting portfolio from money to capital, and thereby, stimulating a higher rate of economic growth (Gregorio, 1996). On the contrary, Fischer \& Modigliani (1978) suggested a negative and nonlinear relationship between the rate of inflation and economic growth (Malla, 1997). Stockman (1981) found a negative relationship between inflation and economic growth. Stockman's model predicts that a high inflation reduces the purchasing power of money, thereby forcing people to reduce their purchases resulting in a fall in the steady-state level of output.

Gokal \& Hanif (2004) worked on Fiji’s economic growth and inflation performance, report a weak negative link, while causality was shown to run from economic growth to inflation. Also, Faria \& Carneiro (2001) by analysing the relationship between inflation and economic growth in Brazil find that inflation does not impact real output in the long run, but that in the short run there exists a negative effect from inflation on output. Lower interest rates enables consumers to borrow more and spend more, and by so doing cause the economy to grow, hence creating inflation. Rising interest rates in turn will encourage people to save more and borrow less as a result reducing the amount of money in circulation causing low demand for goods and services and thus reducing the general price level in an economy. Foreign direct investment helps businesses grow which may create new job openings. The workers who earn incomes add to the collective buying power, leading to more demand for goods and services resulting in higher prices (Narayanasami, 2014). In addition, Ahortor \& Adenutsi (2009) suggest that the long-run static impact of capital accumulation on inflation is negative.

\section{Data Analysis and Interpretation}

Using the Shapiro-Wilk test and the Box-Cox process as means of assessing normality, it was found that data for all the variables were not normally distributed, except inflation. Hence, data for these variables (apart 
from inflation) were normalized (Faraway, 2002; Osborne, 2010). Table 4.1 shows the results of test of normality.

Table 4.1 Tests of Normality

\begin{tabular}{|c|c|c|c|c|c|c|}
\hline & \multicolumn{3}{|c|}{ Kolmogorov-Smirnov $^{\mathrm{a}}$} & \multicolumn{3}{c|}{ Shapiro-Wilk } \\
\cline { 2 - 7 } & Statistic & Df & Sig. & Statistic & df & Sig. \\
\hline INFLATION & .081 & 84 & $.200^{*}$ & .974 & 84 & .091 \\
\hline T-BILLS & .210 & 84 & .000 & .860 & 84 & .000 \\
\hline GDP Growth & .329 & 84 & .000 & .605 & 84 & .000 \\
\hline MKT & .303 & 84 & .000 & .630 & 84 & .000 \\
\hline FDI & .155 & 84 & .000 & .868 & 84 & .000 \\
\hline GFI & .310 & 84 & .000 & .544 & 84 & .000 \\
\hline
\end{tabular}

a. Lilliefors Significance Correction

Sources: Computed Result, 2013, Using SPSS Version 20

However, Table 4.2 now indicates that the data are normally distributed, because the Shapiro-Wilk test values show significance values which are greater than 0.05 .

Table 4.2Tests of Normality (Standardized Variables)

\begin{tabular}{|c|c|c|c|c|c|c|}
\hline \multirow{2}{*}{} & \multicolumn{3}{|c|}{ Kolmogorov-Smirnov $^{\mathrm{a}}$} & \multicolumn{3}{c|}{ Shapiro-Wilk } \\
\cline { 2 - 7 } & Statistic & Df & Sig. & Statistic & df & Sig. \\
\hline T-BILLS & .321 & 84 & .565 & .860 & 84 & .231 \\
\hline GDP growth & .549 & 84 & .234 & .605 & 84 & .465 \\
\hline MKT & .555 & 84 & .216 & .630 & 84 & .144 \\
\hline FDI & .655 & 84 & .444 & .868 & 84 & .564 \\
\hline GFI & .366 & 84 & .409 & .544 & 84 & .099 \\
\hline
\end{tabular}

Lilliefors Significance Correction

Source: Computed Results, 2013, Using SPSS Version

20

To resolve the assumption of stationarity of the variables proposed by Wooldrige (2006), and Granger (1966), we find the natural log of all nonstationary variables, after which Durbin-Watson's statistics is used to verify stationarity of modified data (Nielsen, 2005, Tsay, 1984). Durbin-Watson statistic now reveals the presence of stationarity in data because the DurbinWatson statistics value in Table 4.3 is close to 2.

Table 4.3 Durbin-Watson Statistics after Eliminating Non-Stationarity

\begin{tabular}{|c|c|c|c|}
\hline $\begin{array}{c}\text { Regression } \\
\text { layer }\end{array}$ & $\begin{array}{c}\text { Outcome } \\
\text { Variable }\end{array}$ & Predictors & $\begin{array}{c}\text { Durbin- } \\
\text { Watson }\end{array}$ \\
\hline 3. & Inflation & GDP growth, FDI, GFI, T-BILLS, & MKT \\
\hline
\end{tabular}

Source: Computed Results, 2013, Using SPSS Version 20 
Table 4.4 shows the Pearson's correlation matrix among the variables under consideration.

Table 4.4 Pearson's Correlations

\begin{tabular}{|c|c|c|c|c|c|c|c|}
\hline & & $\begin{array}{c}\text { GDP } \\
\text { growth }\end{array}$ & MKT & Inflation & T-BILLS & FDI & GFI \\
\hline \multirow[t]{3}{*}{ GDP growth } & $\begin{array}{c}\text { Pearson } \\
\text { Correlation } \\
\end{array}$ & 1.000 & $.745^{* *}$ & 0.188 & -0.128 & $.557^{* *}$ & $.632^{* *}$ \\
\hline & $\begin{array}{c}\text { Sig. (2- } \\
\text { tailed) }\end{array}$ & & 0.000 & 0.087 & 0.247 & 0.000 & 0.000 \\
\hline & $\mathrm{N}$ & 84.000 & 84.000 & 84.000 & 84.000 & 84.000 & 84.000 \\
\hline \multirow[t]{3}{*}{ MKT } & $\begin{array}{c}\text { Pearson } \\
\text { Correlation }\end{array}$ & $.745^{* *}$ & 1.000 & 0.071 & $-.281^{* *}$ & $.511^{* *}$ & $.707^{* *}$ \\
\hline & $\begin{array}{c}\text { Sig. (2- } \\
\text { tailed) }\end{array}$ & 0.000 & & 0.524 & 0.010 & 0.000 & 0.000 \\
\hline & $\mathrm{N}$ & 84.000 & 84.000 & 84.000 & 84.000 & 84.000 & 84.000 \\
\hline \multirow[t]{3}{*}{ Inflation } & $\begin{array}{c}\text { Pearson } \\
\text { Correlation }\end{array}$ & 0.188 & 0.071 & 1.000 & $.647^{* *}$ & $.231^{*}$ & 0.206 \\
\hline & $\begin{array}{l}\text { Sig. (2- } \\
\text { tailed) }\end{array}$ & 0.087 & 0.524 & & 0.000 & 0.034 & 0.060 \\
\hline & $\mathrm{N}$ & 84.000 & 84.000 & 84.000 & 84.000 & 84.000 & 84.000 \\
\hline \multirow[t]{3}{*}{ T-BILLS } & $\begin{array}{c}\text { Pearson } \\
\text { Correlation }\end{array}$ & -0.128 & $-.281^{* *}$ & $.647^{* *}$ & 1.000 & 0.055 & -0.148 \\
\hline & $\begin{array}{l}\text { Sig. (2- } \\
\text { tailed) }\end{array}$ & 0.247 & 0.010 & 0.000 & & 0.617 & 0.180 \\
\hline & $\mathrm{N}$ & 84.000 & 84.000 & 84.000 & 84.000 & 84.000 & 84.000 \\
\hline \multirow[t]{3}{*}{ FDI } & $\begin{array}{c}\text { Pearson } \\
\text { Correlation }\end{array}$ & 0.557 & $.511^{* *}$ & $.231^{*}$ & 0.055 & 1.000 & $.422^{* *}$ \\
\hline & $\begin{array}{l}\text { Sig. (2- } \\
\text { tailed) }\end{array}$ & 0.000 & 0.000 & 0.034 & 0.617 & & 0.000 \\
\hline & $\mathrm{N}$ & 84.000 & 84.000 & 84.000 & 84.000 & 84.000 & 84.000 \\
\hline \multirow[t]{3}{*}{ GFI } & $\begin{array}{c}\text { Pearson } \\
\text { Correlation }\end{array}$ & $.632^{* *}$ & $.707^{* *}$ & 0.206 & -0.148 & $.422^{* *}$ & 1.000 \\
\hline & $\begin{array}{l}\text { Sig. (2- } \\
\text { tailed) }\end{array}$ & 0.000 & 0.000 & 0.060 & 0.180 & 0.000 & \\
\hline & $\mathrm{N}$ & 84.000 & 84.000 & 84.000 & 84.000 & 84.000 & 84.000 \\
\hline
\end{tabular}

Source: Computed Results, 2013, Using SPSS Version 20

Evidently, inflation is highly positively and significantly related to MKT and T-bills, MKT is highly positively related to FDI, $\mathrm{r}(82)=0.524, \mathrm{p}$ $=.000$; and T-Bill, $\mathrm{r}(82)=0.647, \mathrm{p}=.000$. This means it is likely that Inflation is positively influenced by, MKT and T-Bills in the regression analysis.

Evidently, Inflation is highly positively correlated with T-Bills, $\mathrm{r}$ (82) $=647, .000$. Also, GDP growth is highly positively correlated with MKT, $\mathrm{r}$ $(82)=0.745, .000$; FDI, r (82) $=0.557, \mathrm{p}=.000$; and GFI, $\mathrm{r}(82)=0.632, \mathrm{p}=$ .000 . Again, MKT is highly positively correlated with FDI, $r(82)=0.511, p$ 
$=.000$; and GFI, $\mathrm{r}(82)=0.707, \mathrm{p}=.000$. It means that it is likely that Inflation is positively influenced by T-Bills in the regression analysis.

Table 4.5 is associated with the KMO and Bartlett's Test of Spericity for the first iteration of the PCA. When the Keiser-Meyer-Olkin Measure of Sampling Adequacy is 0.50 or more, PCA can be pursued, and this is coupled with the need for Bartlett's Test of Spericity to be between .000 and 0.04 in terms of significance (i.e. Sig.), when using 0.05 level of significance. From Table 4.5, it can be agreed with that PCA could be carried out since both conditions are met.

Table 4.5 KMO and Bartlett's Test (1st Iteration)

\begin{tabular}{|l|c|c|}
\hline \multicolumn{2}{|c|}{ Kaiser-Meyer-Olkin Measure of Sampling Adequacy. } & .696 \\
\hline \multirow{3}{*}{ Bartlett's Test of Sphericity } & Approx. Chi-Square & 200.025 \\
\cline { 2 - 3 } & Df & 28 \\
\cline { 2 - 3 } & Sig. & .000 \\
\hline
\end{tabular}

Source: Computed Results, 2013, Using SPSS Version 20

Table 4.6 shows Keiser-Meyer-Olkin (KMO) Measure of Sampling Adequacy and Bartlett's Test of Spericity for the second iteration of the PCA. At this level also, the PCA can be carried out since both statistics associated with Keiser-Meyer-Olkin (KMO) Measure of Sampling Adequacy and Bartlett's Test of Spericity are satisfactory.

Table 4.6 KMO and Bartlett's Test (2nd Iteration of PCA)

\begin{tabular}{|l|c|c|}
\hline \multicolumn{2}{|c|}{ Kaiser-Meyer-Olkin Measure of Sampling Adequacy. } & .583 \\
\hline \multirow{2}{*}{ Bartlett's Test of Sphericity } & Approx. Chi-Square & 151.239 \\
\cline { 2 - 3 } & Df & 10 \\
\cline { 2 - 3 } & Sig. & .000 \\
\hline
\end{tabular}

Source: Computed Result, 2013, Using SPSS Version 20

Table 4.7 shows communalities for the second iteration of PCA. At this level, there is no factor that has an Extraction value below 0.50. This indicates that the remaining variables, INFLATION, T-BILLS, MKT, FDI and GFI are significant for analysis.

Table 4.7 Communalities (2nd Iteration of PCA)

\begin{tabular}{|c|c|c|}
\hline & Initial & Extraction \\
\hline INFLATION & 1.000 & .840 \\
\hline T-BILLS & 1.000 & .872 \\
\hline MKT & 1.000 & .836 \\
\hline FDI & 1.000 & .579 \\
\hline GFI & 1.000 & .748 \\
\hline
\end{tabular}

Extraction Method: Principal Component Analysis

Source: Computer Print, 2013, Using SPSS Version 20 
Table 4.8 gives the model summary of the regression of Inflation from MKT, GDP growth, T-BILLS, FDI, and GFI. The R Square value of 0.523 indicates that this model is quite strong. However, with a higher scrutiny by the Adjusted R Square value of 0.492 , the model is rendered weak, though it can still be a source of good predictions. Table 4.9 informs us of the linearity of this model.

Table 4.18 Model Summary (INFLATION as Outcome Variable)

\begin{tabular}{|c|c|c|c|c|}
\hline Model & $\mathrm{R}$ & R Square & Adjusted R Square & $\begin{array}{c}\text { Std. Error of the } \\
\text { Estimate }\end{array}$ \\
\hline 1 & $.723^{\mathrm{a}}$ & .523 & .492 & .08543 \\
\hline
\end{tabular}

a. Predictors: (Constant), MKT, T-BILLS, FDI, GFI, GDP growth

b. Dependent Variable: INFLATION

Source: Computed Results, 2013, Using SPSS Version 20

Table 4.19 ANOVA $^{\mathrm{b}}$ (INFLATION as Outcome Variable)

\begin{tabular}{|c|c|c|c|c|c|c|}
\hline \multicolumn{2}{|c|}{ Model } & Sum of Squares & Df & $\begin{array}{c}\text { Mean } \\
\text { Square }\end{array}$ & F & Sig. \\
\hline \multirow{2}{*}{1} & Regression & .624 & 5 & .125 & 17.092 & $.000^{\text {a }}$ \\
\cline { 2 - 7 } & Residual & .569 & 78 & .007 & & \\
\cline { 2 - 7 } & Total & 1.193 & 83 & & & \\
\hline
\end{tabular}

a. Predictors: (Constant), MKT, T-BILLS, FDI, GFI, GDP growth

b. Dependent Variable: Inflation

Source: Computed Results, 2013, Using SPSS Version 20

Table 4.9 shows an ANOVA test for the regression of Inflation from MKT, GDP growth, T-BILLS, FDI and GFI. Here too, the F statistic in the table is significant at 0.05 level of significance, $F(5,78)=17.092, p=.000$. This means that Inflation can linearly be predicted by MKT, GDP growth, TBILLS, FDI, and GFI. As a reminder, there are no multicollinearity problems with this model. This is because the Variance Inflation Factors (VIF) of predictors in the coefficients table, Table 4.10 are all less than 10.

Table 4.10 Coefficients (INFLATION as Outcome Variable)

\begin{tabular}{|c|c|c|c|c|c|c|c|c|c|c|}
\hline \multirow{2}{*}{\multicolumn{2}{|c|}{ Model }} & \multicolumn{2}{|c|}{$\begin{array}{l}\text { Unstandardized } \\
\text { Coefficients }\end{array}$} & \multirow{2}{*}{$\begin{array}{c}\text { Standardized } \\
\text { Coefficients } \\
\text { Beta }\end{array}$} & \multirow[b]{2}{*}{$\mathrm{t}$} & \multirow[b]{2}{*}{ Sig. } & \multicolumn{2}{|c|}{$\begin{array}{l}\text { 95\% Confidence } \\
\text { Interval for B }\end{array}$} & \multicolumn{2}{|c|}{ Collinearity Statistics } \\
\hline & & B & $\begin{array}{l}\text { Std. } \\
\text { Error }\end{array}$ & & & & $\begin{array}{l}\text { Lower } \\
\text { Bound }\end{array}$ & $\begin{array}{l}\text { Upper } \\
\text { Bound }\end{array}$ & Tolerance & VIF \\
\hline 1 & (Constant) & .072 & .028 & & 2.596 & .011 & .017 & .128 & & \\
\hline & FDI & .004 & 011 & .033 & .341 & .734 & -.018 & .026 & .638 & 1.566 \\
\hline & GFI & .025 & .013 & .214 & 1.885 & .063 & -.001 & .051 & .474 & 2.109 \\
\hline & T-BILLS & .749 & .091 & .694 & 8.249 & .000 & .568 & .930 & .863 & 1.158 \\
\hline & $\begin{array}{l}\text { GDP } \\
\text { Growth }\end{array}$ & .015 & .017 & .113 & .893 & .375 & -.018 & .048 & .385 & 2.597 \\
\hline & MKT & .002 & .024 & .013 & .094 & .926 & -.046 & .050 & .314 & 3.188 \\
\hline
\end{tabular}


Table 4.10 Coefficients (INFLATION as Outcome Variable)

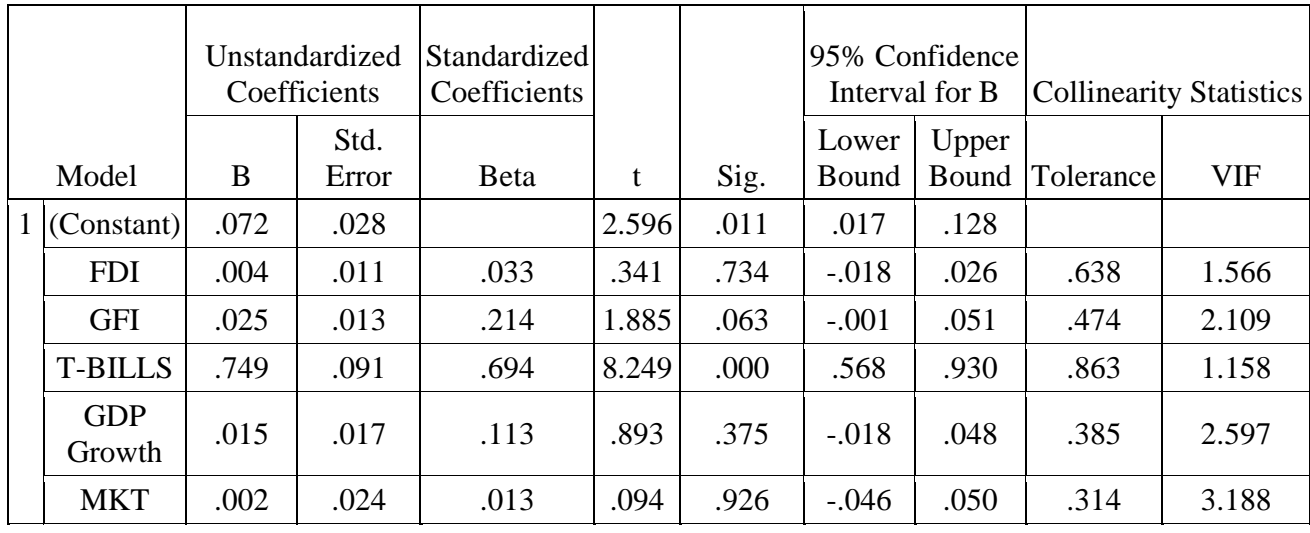

a. Dependent Variable:

INFLATION

Table 4.10 indicates that Inflation is positively and significantly driven by interest rates in Ghana within the time period under consideration. Interest rate is proxied by T-Bill rates. Factors such as market capitalization, gross fixed investment, GDP growth, and foreign direct investments prove insignificant; however, they had positive relationships with inflation.

From Table 4.10, a unit change in interest rate (T-Bill rate) will cause the conditional mean of Inflation to change by 0.749 at a rate of between 0.57 and 0.93 (using 95\% confidence interval) when GDP growth, MKT, FDI, GFI are held constant. The t-statistic of 8.249 explains that the parameter is significant at $5 \%$ level of significance. Therefore, a unit change in interest rates (T-Bills) will have a significant effect on inflation in Ghana when other variables are held constant. The writer, therefore, accepts the alternative hypothesis that interest rates have a positive effect on inflation in Ghana. The result supports economic theory (Mundell, 1965; and Tobin, 1965) and some empirical works including Adu \& Marbuah (2011); and Cochrane (2016) who add that inflation responds positively to nominal interest rate increases. The economic intuition of a positive relationship between inflation and interest rate is that a rise in interest rate raises the marginal cost of capital if there are adjustment costs to capital formation. Businesses may then pass on this higher marginal cost of capital to consumers through higher prices, hence a rise in the rate of inflation (Monetary Bulletin, 2001/4).

\section{Conclusion and Recommendation}

This article is the third of articles emanating from a single study based on structural equation modelling, path analysis. It reports on some influencers of inflation in Ghana. The literature on inflation seems to suggest 
that the causes of inflation are multifaceted and time specific, as well as dependent on the level of development of a country. The study concludes that inflation is positively and significantly driven in the long run in Ghana by interest rates, proxied by treasury bill rates. However, GDP growth, market capitalisation, gross fixed investment, and foreign direct investments proved insignificant. The result of the study makes the writer accept the alternative hypothesis that interest rates have a positive effect on inflation contrary to the Old-Keynesian models that provide the standard intuition that a rise in interest rates lowers inflation. It supports the Fisher relation; and Cochrane (2016) who asserts that when conditions including adequate fiscalmonetary co-ordination operates, pegs can be stable and inflation responds positively to nominal interest rate increases.

The implications of the result are that, if interest rates are brought down, it will cause a positive significant reduction in the rates of inflation in Ghana; and government budget deficits that are financed by government borrowing from the domestic credit market raises treasury bill rates and cost of capital and cost of production generally, resulting in higher prices of goods and services. Also, inflation in Ghana, within the study period, was cost-push in nature. This study lends support to the fact that inflation reacts positively to changes in interest rates; therefore, researchers and policymakers must consider it critical for national development. The Central Bank of Ghana and the Treasury Department must be critical with the fixing of prime rates and treasury bills rates respectively, while the government of Ghana is advised to drastically reduce its involvement in the domestic credit market. In addition, Ghana Statistical Service should periodically review the components of the national baskets of goods and services that determine inflation in Ghana to reflect changes in demand and supply of goods and services in the Ghanaian economy. This article fails to investigate and explain the causality between inflation and interest rate, and why major macroeconomic variables such as GDP growth, market capitalisation, and foreign direct investment had insignificant effect on inflation in Ghana within the time period under consideration. It is therefore, recommended that future studies should investigate causality between inflation and interest rates; and the appropriate level of interest rates that will match with appropriate rates of inflation for economic growth.

\section{References:}

1. Adu, G., \& Marbuah, G. (2011). Determinants of Inflation in Ghana: An Empirical Investigation.

2. South African Journal of Economics, Volume 79, Issue 3, September 2011, Pages 251-269 
3. Ahortor, C. R. K., \& Adenutsi, D. E. (2009). Inflation, capital accumulation and economic growth in import-dependent developing countries. A paper prepared for the 14th annual conference on econometric modelling for Africa 8-10 July 2009, Abuja, Nigeria

4. Andersson, M., Masuch, K. \& Schiffbauer, M. (2009). Determinants of inflation and price level differentials across the euro area countries. European Central Bank Working Paper Series, NO 1129

5. Barimah, A., Quartey, P., \& Andinur, J. (2013). Inflation, foreign direct investment and economic growth in Ghana. MPhil Thesis, Department of Economics, University of Ghana

6. BoG (2015). Inflation Analysis and Outlook . Bank of Ghana Monetary Policy Report, Volume 4 No.3/2015,

7. BoG (2016). Inflation Report: Bank of Ghana Monetary Policy Report, Volume 4 No.1/2016

8. Cochrane, H. J. (2016). Do higher interest rates raise or lower inflation? $\mathrm{t}$ http://faculty. chicagobooth.edu/john.cochrane/research/papers/fisher.pdf $\quad$ (26 $^{\text {th }}$ January, 2017).

9. Cooper, R. D., \& Schindler, S. P. (2011). Business research methods. $11^{\text {th }}$ ed, McGraw-Hill Higher Education, International Edition

10. Databank Research, Key GSE Market Statistics, Graphic Business, Tuesday, February 24 to March 2, 2009.

11. Dornbusch, R., Fisher, S., \& Startz, R. (2004). Macroeconomics. $9^{\text {th }}$ ed., Tata McGraw-Hill Publishing Company Limited, 7 West Patel Nagar, New Delhi 110008.

12. Enu, P., \& Havi, D. E. (2014). Macroeconomic Determinants of inflation in Ghana: A Co integration Approach. International Journal of Academic Research in Business and Social Sciences July 2014, Vol. 4, No. 7

13. Fama, E. (1981). Stock returns, real activity, inflation and money. American

14. Economic Review, 71, 545-564. 0119 Faraway, J. J. (2002). Practical regression and ANOVA using R. International Journal of Applied Economics, 21 (2): 111-121. Faria, R. J. \& Carneiro, G. F. (2001). Does high inflation affect growth in the long and short run? Journal of Applied Economics, Vol. IV, No. 1, 89-105

15. Finance, Banking, and Money (v.2.0).

16. http://2012books.lardbucket.org/pdfs/finance-banking-and-moneyv2.0.pdf

17. Frimpong, D. E. (2010). Inflation goes down. Daily Graphic, Thursday, April 15, 2010, page 1.Ghana: Inflation rate from 2010 to 
2020 (compared to the previous year). https://www.statista.com/statistics/447576/inflation-rate-in-ghana/

18. Gokal, V. \& Hanif, S. (2004). Relationship between inflation and economic growth. Working Paper 2004/04, Economics Department, Reserve Bank of Fiji, Suva, Fiji. Retrieved on 18/11/13, from http://www.reservebank.gov.fj/docs/2004_04_wp.pdf

19. Gyebi, F., \& Boafo, K. G. (2013). Macroeconomic determinants of inflation in Ghana from 1990 - 2009. International Journal of Business and Social Research (IJBSR), Volume -3, No.-6, June, 2013

20. Granger, C. (1966). The typical spectral shape of an economic variable. Econometrica, 34, 150-161

21. Hubbard, G. R. (2008). Money, the financial system, and the economy. $6^{\text {th }}$ ed., Pearson Education, Inc.

22. Institute of Statistical, Social and Economic Research (2009). The state of the Ghanaian economy in 2008. University of Ghana, Legon.

23. Lim, C. Y., \& Sek, K. S. (2015). An examination on the determinants of inflation. Journal of Economics, Business and Management, Vol. 3, No. 7

24. Madiha, M., Zahib, A., Shoaib, B. Mahmood, M., Nyanab, S. (2013). Impact of inflation and economic growth on foreign direct investment: Evidence from Pakistan. Interdisciplinary Journal of Contemporary Research in Business, Institute of Interdisciplinary Business Research 236 Vol. 4, No 9

25. Mankiw N. G. (2003). Macroeconomics. $5^{\text {th }}$ ed., worth Publishers, 41 Madison Avenue, New York, NY 10010.

26. Mansfield, E., \& Behravesh, N. (2001). Economics USA. $6^{\text {th }}$ ed., W. W. Norton and Company, Inc., 500 Fifth Avenue, New York, N.Y. 10110

27. Monetary Bulletin (2001/4). Box 5: The relation between interest rates and inflation. A quarterly publication of the Central Bank of Iceland, Vol. 3 no. 4 November 2001Monetary Bulletin http://www.cb.is/lisalib/getfile.aspx?itemid $=4532$

28. McConnell R. C. \& Brue L. S. (1996). Macroeconomics. $13^{\text {th }}$ ed., McGraw-Hill, Inc. Narayanasami, B. (2014 ). How do foreign direct investments and foreign portfolio investments affect domestic inflation? Quara

29. Nielsen, H. B., (2005). Non stationary time series: Conintegration and spurious regression, Statistical Theory of Econometrics, Fall, pp. 4-22.

30. Nellis, G. J., \& Parker, D. (1996). The essence of the economy. $2^{\text {nd }}$ ed., Prentice Hall Europe. 
31. Oppong, A., Abruquah, A. L., Agyeiwaa, D., Owusu, D. A., Quaye, I., \& Ashalley, E. (2015).

32. Key determinants of inflation in Ghana. British Journal of Economics, Management \& Trade 8(3): 20-214, 2015, Article no.BJEMT.2015.111

33. Osborne, W. J \& Waters, E.(2002). Four assumptions of multiple regression that researchers should always test. North Carolina State University and University of Oklahoma. Practical Assessment, Research, and Evaluation, 8(2). Retrieved on November, 2013, from http://ericae.net/pare/getvn.asp?v $=8 \& n=2$

34. Pettinger, T. (2011). Is inflation caused by economic growth? economicshelp

http://www.economicshelp.org/blog/3511/economics/is-inflationcaused-by-economic-growth/

35. Salmanpour, A. \& Bahloli, P. (2011). Inflation, inflation uncertainty and factors affecting inflation in Iran. World Applied Sciences Journal 14 (8): 1225-1239

36. Sauer, S. (2007). Discretion rather than rules? When is discretionary policy-making better than the timeless perspective? European Central Bank, Working Paper Series No 717 / January 2007

37. Slavin L. S. (2002). Economics. $6^{\text {th }}$ ed.UK, Mcgraw-Hill Companies Inc.

38. Totonchi, J. (2011). Macroeconomic theories of inflation. 2011 International Conference on Economics and Finance Research, IPEDR vol.4 (2011, IACSIT Press, Singapore

39. http://www.investopedia.com/terms/q/quantity_theory_of_money.asp \#ixzz4VwdmsitQ Tsay, R. S. (1984). Order selection in stationary autoregressive models. Annals of Statistics, 12, 1425-1433.

40. WAMI (2012). Inflation and growth in the WAMZ: Evidence from a threshold analysis.West African Monetary Institute (WAMI). WAMI Occasional Paper Series No.1. Retrieved from http://www.wamiimao.org on $24 / 08 / 2015$

41. Wooldridge, M. J. (2006). Introductory econometrics: A modern approach. $3^{\text {rd }}$ ed.

42. Thomson Higher Education, 5191 Natorp Boulevard, Mason, OH 45040, USA 